\title{
Education Patterns in the Context of an Emergency
}

\author{
Nancy Hatch Dupree
}

\begin{abstract}
Education in Afghanistan is in crisis. This discussion examines the context that structures the Afghan crisis. Amongst the vast plentitude of challenges confronting Afghanistan today, those in education are the most paradoxical. On the one hand, one is told that education forms the foundation upon which all reconstruction rests. On the other hand, education remains the most severely underfunded sector in humanitarian assistance to Afghanistan. ${ }^{1}$
\end{abstract}

\section{Précis}

L'éducation en Afghanistan est en crise. Le présent exposé examine les contextes structurant cette crise afghane. Dans la vaste multitude de défis auxquels l'Afghanistan contemporain faitface, les défis éducationnels sont les plus paradoxaux. D'un côté on entend le message selon lequel l'éducation forme le fondement surlequel toute reconstruction nationale repose. D'un autre côté, l'éducation demeure le plus sévèrement sous-financéde tous les secteurs d'action humanitaire en Afghanistan.

\section{Today}

Since the rise of the Taliban Islamic Movement (now styled the Islamic Emirate of Afghanistan) in 1994, ${ }^{2}$ the crisis in education has been exacerbated by official pronouncements banning girls from attending school and female teachers from teaching. Donors have predictably reacted with their own principle-centred statements. ${ }^{3}$ Education continues to deteriorate as the impasse hardens.

The seriousness of this deterioration becomes starker when seen against the already abysmal state of education in

Nancy Hatch Dupree is Senior Consultant at the
ACBAR Resource and Information Centre
(ARIC) of the Agency Coordinating Body for
Afghan Relief(ACBAR) in Peshawar, Pakistan.
Afghanistan before the conflict began after the 1978 coup d'etat. Pre-war trends persist and provide useful patterns of comparison. Economic, regional and gender imbalance in literacy rates were abundantly noticeable. The 1975 literacy rate was estimated at $\mathbf{1 1 . 4}$ percent ( $18.7 \%$ males; $2.8 \%$ females). In urban settings, 25.9 percent $(35.5 \%$ males; $14.8 \%$ females) of the population six years old and over were literate, but in rural areas only 8.8 percent $(15.7 \%$ males; $0.6 \%$ females, in some provinces $0.1 \%) .{ }^{4}$ Regionally, 32 percent of the students lived in and around the capital city of Kabul in 1978, compared with only 3.3 percent living in the central mountains. 5

The absence of reliable data and the unstable political situation render statistics meaningless in 1998. Nevertheless, it does not take much imagination to calculate the enormity of the emergency in light of the war-destroyed infrastructure, the loss of qualified staff, the inattention of national authorities, and donor reluctance. Fifteen NGOs, both Afghan and international, operate in the field. They function in 25 of Afghanistan's 32 provinces, providing services to perhaps some 250,000 individuals, mostly on primary levels. This meets only a fraction of the needs. Moreover, projects are scattered, often intermittent because of funding shortages, and, with notable exceptions, the quality is frequently inconsistent and woefully below minimum standards.

Among refugee populations in Pakistan there are an estimated 230,000 children of primary age in the officially recognized refugee camps and settlements composed largely of families from rural areas. Of these children, some 90,000 receive educational services. $^{6}$ For urban populations living outside the official camps, education is a scandal.

After the Taliban swept into Kabul in September 1996, scores of families left, only to find that assistance to refugees in Pakistan had been cut to a bare minimum. Schools outside the officially administered camps had all but disappeared. Donors had decreed that schools retarded repatriation and attracted new refugees.

Indeed, it was the rapid decline of education in Kabul that induced many families to leave. There wereno schools for girls, services at boys' schools were deplorable because 70 percent of their teachers had been women who were no longer permitted to work, and the conservative orientation of the new authorities threatened to confine the curriculum solely to religion. Even Taliban officials keep their families in Pakistan so that their children could attend schools with widerhorizons. Entrance to Pakistani-run schools, however, is difficult and expensive. So while there is a tremendous demand, access to qualified facilities is slight. Opportunists thrive under such conditions and their sign boards beckon anxious parents in almost every Peshawar alleyway. In return for the fees, however, the majority offer precious little in the way of qualified teachers, uniform textbooks, curriculum, or supplies.

Both inside and outside Afghanistan, education had become such a burning issue by mid-1997 that aid providers met in a series of meetings seeking new, common strategies for improving access, quality, and capacities. ${ }^{7}$ Before devising strategies, however, it is well to be aware of the existing education fabric. What patterns existed before the war? What purposes did education serve? Who benefited, in what ways? These questions form the focus of this discussion.

\section{Way Back}

Education has always been a treasured ideal in this region where renowned centres of learning flourished during various historical periods. In addition, since seeking knowledge is sanctified 
by the Islamic injunction that all good Muslims, including women, should seek education so as to better provide social justice for the community, all knowledgeable individuals, not only scholars, are accorded measurable respect. Thus one finds that bonds between teachers and pupils are strong, second only to those governing the rights and obligations of families.

In practice, however, the ideal was confined largely to elites flourishing at the Islamic courts of the Samanids in Balkh in the 9th century, the Ghaznavids in Ghazni during the 10th and 11th centuries, the Timurids in Herat in the 15th, and in Kandahar in the 18 th century.

By the 19th century, this high tradition of scholarship provided the form for traditional learning, although much of the creativity of earlier times had been lost. It was focused on the transmission of Islamic doctrine through the institutional structure and organization of madrassas centered around reputed scholar/tutors with their devoted disciples. These centres of learning were private concerns attached to mosques and supported by communities as well as rich patrons. There was no uniformity incurriculum. Teaching methods relied heavily on recitation and memory.

The lower levels of educational establishments were also found in community-supported mosques in villages, district towns and city neighbourhoods. Here, instruction, again with no uniform curriculum, dwelt almost exclusively on imparting knowledge of the ritual, beliefs, practices and moral teachings of Islam taught by the rote reading of the Koran and other popular literary devices utilizing classical Persian poetry and prose with a goodly admixture of customary tribal beliefs. Two popular texts, Panj Ganj, and, Kulliyat-iChaharKitab, expound on the duties of good Muslims, correct behaviour, and other types of religious knowledge. ${ }^{8}$ Unfortunately, numerous superstitions and prejudices also appear. Attitudes concerning female foibles and male superiority are entrenched at a very early age through these texts.
The local mosque schools were too often taught by mullahs with minimal education; sometimes they were barely literate. They relied on recitation, memorization and endless repetition. Comprehension was of little relevance and a favoured teaching aid was a long stick used to jar the inattentive unlucky enough to err.

Although respect for learning continued as the end of the 19th century approached, the bulk of the population remained illiterate. Learning to read the Koran by rote did not necessarily mean learning to write.

\section{Reforms Begin and End: 1880s-1929}

Although Amir Sher Ali opened what might be called the first modern schools as early as 1868 , the absence of educated subjects irritated the creator of the first centralized nation-state in Afghanistan.

Amir Abdur Rahman (1880-1901) relates that on coming to the throne in 1880 , he sought 30 clerks who could read and write, but could only find three. As a result he made education a pillar of his reforms. He opened schools in major towns and had the foresight to order the printing of thousands of books.

Thus education served to strengthen the Amir's administration, but his vision went far beyond this. His ultimate goal was to establish a centralized, integrated autocratic nation-state and to extend his authority over all aspects of society so that Afghanistan might acquire a respected place within the comity of nations. Educated subjects, including women, were imperative, he said. Buthe also insisted women remain in seclusion, seeing nothing inconsistent in the two:

Owing to the wisdom of our Holy Prophet, who commanded that women under no circumstances should ever leave their houses without the consent and permission of their husbands, women should be allowed to do so for one purpose only, that of being educated. ${ }^{9}$

The Amir also devoted much of his efforts to reorganizing a state-super- vised religious hierarchy which effectively curtailed their heretofore domination of education. The intent was not to destroy the religious establishment, but to subordinate it to the centre, thereby co-opting high officials at major religious institutions as spokesmen for the legitimacy of the Amir's modernization policies. ${ }^{10}$

The dynamics between the traditional and the modern became more apparent during the reign of Amir Abdur Rahman's son and successor, Amir Habibullah (1901-1919), who had neither the ruthlessness nor the political skills of his father. As a consequence the religious establishment regained some of its lost influence, although the Amir diligently furthered several aspects of modernization so as to continue to improve the nation's image while Russia and England played their Great Game.

The first truly modern secular school was Habibiya, opened in 1903 . It was modelled after Aligarh College in India. In 1904, a school for the children of notables was established, which became the military college known as Harbiya headed by a Turkish military officer. The primary school system was expanded in 1915 and textbooks as well as instruction were provided free.

King Amanullah (1919-1929) expanded his father's education services. Eight modern, foreign-language schools, five for boys and three for girls, were active by the end of his reign; some were upgraded to high schools, with French, German and English instruction at the boys schools. Turkish, French, German and Indian female teachers taught science and foreign languages at Masturat, the first school for girls which opened in 1921. By 1929, the total enrolment in formal state-sponsored secular schools for girls numbered $700 .{ }^{11}$

Students, both boys and girls, were mostly, although not entirely, upper elites. Years later, even after education became more widely accessible to the middle class, these early schools remained elitist centres of learning. By 1978 , graduates of state-run schools in Kabul dominated top positions in the 
bureaucracy; most prominent political leaders during the war years, on both the left and the right, were also graduates of this system.

By 1929 , several patterns had been set. First, leaders emerged from state secular schools, not from private madrassas. Second, most, if not all, substantive improvements in education were provided by outside assistance. This trend continued particularly as university faculties were later established. ${ }^{12}$ Third, this period marks the beginning of the bifurcation of education into two parallel systems: traditional religious and modern secular. From this time onward the influence of one over the other intensified according to political developments, and the divide was often racked with tensions.

King Amanullah's zeal for modernization struck out against many conservative customary practices. Inflamed, the traditionalists revolted. As the tribalmomentumescalated, theKing was confronted with numerous demands, number one among which was the closure of secular schools, particularly those for girls. A Pushtun tribal army advancing from the east unseated the king and its Tajikleader ruled Kabul forninemonths untilhe too was toppled in October 1929.

\section{Consolidation: 1929-1960s}

King Nadir Khan (1929-1933) came to the throne with the support of the tribal forces that helped him conquer Kabul, and the religious leaders gained more influence as a result. Many of Amanullah's reforms were abandoned, but secular education, including schools for girls in separate facilities, expanded both geographically as well as academically under royal patronage.

King Nadir found his throne shaky and his coffers empty. To remedy this, secular education was promoted not only to help secure loyalty towards the monarchy but also to produce the manpower needed to increase productivity. While Islam was evoked at every opportunity so as to strengthen national unity, the gradual, cautious promotion of secular education was employed in order to convince traditionalists that Is- lam and modernization were compatible.

These policies continued to mould education over the next three decades and the sector grew as an adjunct to development by preparing loyal technocrats and bureaucrats for an expanding government.

Statistics in Afghanistan are always risky, but they do indicate patterns. ${ }^{13}$ The growth of formal government schools appear thus:

1930: 13 institutions and 1,590 students,

1967: 2,567 institutions and 497,911 students. $^{14}$

It was during this time of major growth that compulsory primary education was constitutionally enshrined, first in Article 20 of the 1931 Constitution. Article 34 of the 1964 Constitution stated that education is a right of every Afghan and that education shall be provided free by the state, that the state is obliged to provide suitable facilities, and that it is a state duty to guide and supervise. This Article also allowed Afghan nationals to establish technical and literacy schools outside the state system, the curricula of which, however, were still to be determined according to state laws.

The government neverhad the funds or the capability to realize this constitutional ideal. Nevertheless, the concept of the right of every citizen to enjoy free compulsory education was a matter of pride, which is deeply ingrained in the minds of educated Afghans today. They are loathe to see this right compromised.

\section{The Explosion: 1960s and 1970s}

By the time the 1964 Constitution was promulgated, the government, feeling securely backed by a strong military base of power, had already launched an unprecedented surge in development and reforms including support for the voluntary end of purdah and removal of the veil. Teaching became an acceptable career for women active in public life. Primary schools and Kabul University became co-educational, while middle and high schools remained in separate facilities. As the industrial sector grew, rural-urban migration increased, giv- ing many more children access to schooling on all levels. In addition, foreign investors in the new industrial sector sent more and more students, both men and women, overseas for higher training. By 1974 , some 1,500 a year were leaving for studies abroad.

Of course, traditional mosque schools continued to function in uncounted numbers, with all the shortcomings described still intact. These were still largely supported by their communities, but in keeping with its consistent desire to retain a tight grip on all things educational, the central government introduced regulatory measures toward the end of the 1960s to standardize and coordinate the activities of those madrassas established through local initiatives.

By 1978, the number of schools had risen to 3,825 with over a million students taught by almost 40,000 teachers. ${ }^{15}$ Another set of statistics indicates that only 12 percent of these schools were for girls, but of course many girls attended co-educational schools. Others still studied at home where their instruction may well have been superior to what they would have received in schools. The percentages of school-age girls enrolled in primary schools $(8.6 \%)$, middle schools $(3 \%)$ and Lycee with grades $10-12(1.4 \%)$, although discouraging, were nevertheless twice the number in grades $1-9$ and five times the number in grades 10-12 compared to the 1960 s. ${ }^{16}$

Amir Abdur Rahman would no doubt have been able to find 30 clerks, male or female, to help with his administration by 1978 . Nevertheless, in terms of the requirements for truly functional literates, the situation in 1978 was fully as inadequate as it had been in 1880 . Indeed, the Amir's search would have been further beset by masses of only marginally employable school graduates. By 1978 , an estimated 70 percent of school graduates were unemployed. Graduates were either ill-trained, overly-trained or, as was often the case, capable only of performing routine administrative jobs which were already filled. 
The education sector, therefore, was inadequate even before the onset of war in 1978.

\section{What Happened?}

For one hundred years many schools representing very large expenditures of money and effort had come into being, yet Afghanistan's education achievements remained the lowest in Asia. ${ }^{17}$ Where did the problems lie?

On the upper administrative levels, the Ministry of Education had all the departments requisite for a good delivery system, but there was a sad absence of dynamic policy-making leadership. This should not have been, for the ministers and high officials were chosen from among the most capable, forwardlooking Afghans available; many held advanced degrees in education from respected foreign academic institutions. But it was difficult to maintain any consistency. Ministers, being political appointees each with their own agendas, were removed with great rapidity before they could affect any lasting impact. Between 1964 and 1973, five different governments came and went.

Worse, ministers often succumbed to a general malaise because they could not persuade the King to issue the necessary authorizations that would enable them to initiate new approaches. The King was dilatory in this regard because of the influence of overly cautious family advisors. They feared that changes toward a more effective, broadbased education system would ultimately undermine the autocratic position of the royal elite. Subsequent events proved they were right.

In the meantime, the system plodded along with many difficulties, many of which are mirrored in today's inadequacies. Rural-urban, geographic, elite-commoner and gender gaps persisted. Quantity did not mean quality. Despite the existence of several teachertraining institutions, lectures on good techniques did not guarantee good teaching. Rote memorization continued.Classrooms were teacher-centered, not child-centered. Teachers expounded, students listened, rarely pos- ing questions, and seldom interacting in discussions. Remembering, not thinking, was important. Lessons were monotonous and boring, students passive and inattentive. Many dropped out.

Dependable textbooks were limited. Lessons were focused on facts, not ideas. Supplementary teaching aids and reading materials providing more entertaining lessons were all but nonexistent. And, even when they were available, few cared to take advantage of them. Students preferred to follow prescribed texts tenaciously, objecting to the intrusion of other materials. Also, it is questionable whether supplementary readings would have been very inspiring since all published material was subject to state-censorship throughout the twentieth century.

Good teachers seldom wished to serve outside the cities; those who did serve in the provinces seldomattempted to identify with the communities in which they were posted. Certainly the concept that teachers can perform leadership roles was seldom realized. Trained teachers most often stood apart. The communities preferred it that way for they regarded teachers as outsiders, as government agents, to be held warily at arms length. Of course there were notable exceptions.

Already noted is the fact that foreigners of all sorts and languages were conspicuous on the education scene from the time secular education was introduced, both physically as teachers and advisors and as funders. This presence of foreigners in the sensitive arena of moulding the minds of youth disturbed the traditionalists and conservatives, many of whom found secular education repugnant. This exacerbated tensions.

Failings within the bureaucracy were responsible for much of the sterility and stagnation that characterized the entire system by 1978 . Today exactly the same mind-sets affect officials, many of whom are hold-overs from pre-war days. They stubbornly resist innovations; change is anathema to them. Having survived the King, Daud, Taraki, Najibullah, Rabbani, and now the Taliban, they know that continued sur- vival depends on keeping the system functioning without rocking any boats. As in the past, these officials are perpetuators, not innovators. This is a big stumbling block.

This is particularly evident in regard to curriculum. In the past apathetic attitudes toward school attendance, the high drop out rates and the graduation of semi-functional literates to whom critical and analytical thinking was alien, were duelargely to the rigidity of old curricula.

In the rural areas, the question was: Why waste time going to school when what Ilearned there is not relevant to my daily life? Even the highly touted revised textbooks from the 1960 s and 1970s were oriented toward upper and middle class urban populations.

In addition, there was little understanding that education should enhance interacting economic and social expectations. In urban settings, students were led toward social behaviour that was not gradually adjusted to traditional mores nor attuned to the social and economic needs they required to cope with the complexities of rapid change. ${ }^{18}$ The secular education system did not provide a bridge between the new and the old, and therefore it was unsuccessful in producing agents for gradual progressive change compatible with societal ideals. Furthermore, the traditional religious schools also failed to provide fresh interpretations combining change with continuity. They too had nobridge between the past and the present.

Instead, while opening new frontiers of knowledge, the growth of education intensified rivalries in economic competition, widened political and religious disagreements, and sharpened appetites for a bigger share in the affairs of government. ${ }^{19}$ Voluble political activity resulted. ${ }^{20}$

Despite these negatives, increasingly favourable attitudes toward modern schools did evolve during the 1960 s as the communication infrastructure improved and rural-urban migration increased. Sadly, this patiently constructed positive trend changed almost 
overnight after theSovietinvasion. Education in general, and modern education in particular, became anathema as the Russians heavily sovietized the system. ${ }^{21}$

Due to broadening experiences during exile, this hostility has again been replaced with open demands for schooling from many directions, including groups which once found secular education repugnant. There is now an opportunity to forge a modern system better adapted to Afghan traditions and society.

\section{Where Are We Now?}

First, it is clear that much of what we are witnessing today is not new but an exaggerated continuation of historical social processes which must be understood.

Second, recognizing that during the entire period under discussion stringent state regulation was a dominating feature, now is a time of relative freedom. Advantage should be taken of in this hiatus to develop model systems, methods and materials that can serve to convince whatever leadershipemerges that modern education can provide an acceptablebridge between the old and the new. That education will lead to individual and national prosperity without impinging on valued cultural ideals.

Third, since positive renewed demands for education are emerging among new segments of the society virtually untouched by the former system, one must ask what has created this new desire. What aspirations are being sought? Are they economic, or something deeper? Are individuals perhaps seeking to assuage the indignities of conflict and exile by acquiring that respect traditionally accorded to the educated?

Fourth, events have brought to the fore a new dominant leadership that is not prominently from the graduates of the former elite education system. These individuals are, nevertheless, graduates of non-Afghan institutions where they have imbibed ideas, which are in many ways equally as objectionable to many Afghans as the ideas pro- pounded when secular schools were first introduced. The conviction that the former Western-oriented system corrupted the entire educational system, and with it many aspects of society, drive many in the new leadership. Believing also that education powerfully influences the minds of the young, they feel it imperative to carefully monitor this sensitive realm. Fear of outside intervention is abidingly strong.

Fifth, the ages-old respect for learning is still present;none of the new leaders have repudiated the right of all to seek education. Education need not, therefore, automatically return to the Dark Ages. Tensions between traditional and modern systems will continue, but inconsistencies abound. Individual officials change with regularity. What is allowed today may be disallowed tomorrow; equally, what is disallowed today may be allowed tomorrow. Out of these types of confusions future possibilities will arise.

\section{Notes}

1. For example, in the 1997 UNConsolidated Appeal for Assistance requesting U.S.\$133 million, only 5 percent was requested for education, and of that only 0.163 percent had been pledged by midterm. See United Nations, Afghanistan: 1997 Consolidated Appeal for Assistance MidTerm Review (Islamabad: United Nations Development Program/Afghanistan, 1997), 18 and Annex I.

2. William Maley, ed., Fundamentalism Reborn?: Afghanistan and the Taliban (London: Hurst \& Company, 1998).

3. Nancy Hatch Dupree, "Afghan Women under the Taliban," in Maley, op.cit., 14566.

4. Afghan Demographic Studies (Buffalo: State University of New York at Buffalo, 1975).

5. United Nations Development Program, Kabul, Afghanistan, Afghanistan Rehabilitation Strategy: Action Plan for Immediate Rehabilitation (Islamabad: UNDP/Afghanistan, 1993), vol. VII, Social Services, 98.

6. Andrea B. Rugh, "Education for Afghans: A Strategy Paper" (Islamabad: Save the Children US/UNICEF, 1998), 1.

7. Ibid.

8. Nazif M. Shahrani, "Local Knowledge of Islam and Social Discourse in Afghanistan and Turkistan in the Modern Period," in
Turko-Persia in Historical Perspectioe, edited by Robert $\mathrm{L}$. Canfield (Cambridge: Cambridge University Press, 1991), 161-88.

9. Amir Abdur Rahman Khan (Sultan Mahomed Khan, ed.), The Life of Abdur Rahman, Amir of Afghanistan (London:John Murray, 1900), ii, 198.

10. Ashraf Ghani, "Islam and State-Building in a Tribal Society: Afghanistan 18801901," Modern Asian Studies 12, no. 2 (1978): 269-84.

11. Fahima Rahimi, Women in Afghanistan (Liestal,Switzerland:Stiftung Bibliotheca Afghanica, 1986), 44.

12. Louis Dupree, Afghanistan (Princeton: Princeton University Press, 1980), 598.

13. The UNDP Human Development Report 1997 (New York: UNDP, 1997) did not include education and numbers of other figures for Afghanistan because no reliabile data were available.

14. AshrafGhani, "Future of the Past," WUFA 5, no. 4, (1990), "Special Issue: InternationalSeminar on Social and Cultural Prospects for Afghanistan in Tribute to the Memory of Louis Dupree" (Peshawar, Pakistan: Writers Union of Free Afghanistan, 1990), 159.

15. University of Nebraska at Omaha(UNO), The Status of Education in Afghanistan (Peshawar, Pakistan: UNO Education Sector Support Project, 1994), i, 13.

16. Ministry of Education, Educational Statistics 1974 (Kabul: Ministry of Education, Department of Planning, 1974), in Panela A. Hunte, Women and the Development Process in Afghanistan (Washington, DC: AID/ NE-C-1487 Afghanistan, Project 298-035: Regional Training for Women, 1978), 27.

17. Out of 174 countries in the development index, Afghanistan ranked 169 in education with only five African nations belowit. United Nations Development Program, Human Development Report 1996 (New York: UNDP, 1996), 165.

18. Erica Knabe, Commoners, Climbers and Notables (Leiden: E.J. Brill, 1997).

19. RalphH.Magnus and EdenNaby, Afghanistan: Mullah, Marx, and Mujahid (New Delhi: HarperCollins Publishers India, 1998).

20. Louis Dupree, “The 1969 Student Demonstrations in Kabul," ALFS Reports, South Asia Series xiv, no. 5(Hanover, NH: American Universities Field Staff, 1970).

21. Bahaouddin S. Majrooh and S.M.Y.Elmi, "Education in Afghanistan: Past and Present. A Problem for the Future," in The Sovietization of Afghanistan (Peshawar: Afghan Jehad Works Translation Centre, 1986), 126-41. 口 